\title{
Antrenman Yükü
}

\section{Training Load}

\section{DERLEME/ REVIEW}

\section{Zeki AKYILDIZ ${ }^{\dagger}$}

Pamukkale Üniversitesi, Spor Bilimleri Fakültesi, Antrenman ve Hareket Anabilim Dalı, Denizli https://orcid.org/0000-0002-1743-5989

\section{Yayın Bilgisi}

Gönderi Tarihi: 17.02.2019

Kabul Tarihi: 02.10.2019

Online Yayın Tarihi: 31.12.2019

DOI: $10.33459 /$ cbubesbd.528148
Öz

Antrenman yükünün takibi takım sporcularında ve bireysel sporcularda antrenmanın dozunu ayarlayabilmek, oyuncuların sakatlık riskini azaltabilmek ve performanslarını artırabilmek içindir. Antrenmanlarda ve müsabakalarda elde edilen antrenman yükü verileri çeşitli yazılım, donanım ve formüllerle hesaplanarak oyuncuların antrenmanlarına yön verilmesini kolaylaştırmaktadır. Günümüz spor dünyasındaki oyun temposunun yüksekliği nedeniyle oyuncuların bu tempoya ayak uydurmalarının sağlanabilmesi için antrenman șiddetlerinin oyun temposuna yakın olması sağlanmaktadır. Takım sporlarında ligin durumu düşünüldügünde her hafta sonu müsabaka yapılması, oyuncuların yeterli toparlanamaması, hafta içerisindeki antrenmanlarda hafta sonu yapılacak olan müsabakaya hazır olma isteği sonucu ani antrenman yükünün yükseltilmesi oyuncuların sakatlık risklerini artırmaktadır. Antrenman yükünün takibi de oyuncuların performanslarını optimum seviyeye getirebilmek için, minimum maliyetten maksimum maliyete kadar çeşitli yelpazede kullanabilen yöntemleri içermektedir. Günümüz spor dünyasında oyuncuların sakatlıkla yüzleşmeden önce atletik performans parametrelerini optimum seviyeye getirmesi gereklidir. Spor bilimciler, kuvvet kondisyon koçları ve atletik performans antrenörleri sakatlık öncesi performansı optimum düzeye getirmeye çalışırken sakatlığı da önleyebilmek için antrenman yüklerini takip etmektedir. Çünkü oyuncuların sakatlık durumlarında oyuncu psikolojik olarak negatif etkilenirken, kulüplerde ekonomik olarak negatif etkilenmektedir. Bu derleme spor bilimciler, kondisyon koçları ve performans antrenörlerinin takımlar ve bireysel oyuncularda sakatlıktan uzak optimum performans seviyelerini sağlayabilmek için antrenman yükü ile ilgili teorik ve pratik bilgiler vermek amacıyla hazırlanmıştır.

Anahtar Kelimeler: Antrenman Yükü, İç Antrenman Yükü, D1ş Antrenman Yükü, Spor Sakatlıkları.

\begin{abstract}
Training load monitoring is used in team athletes and individual athletes to adjust the dose of training, to reduce the risk of injury to the players and to increase their performance. Training load data obtained in training and competitions is calculated with various software, hardware and formulas and facilitates the training of the players. Due to the high game tempo in today's sports world, it is ensured that the training intensities are close to the game tempo in order to ensure that the players keep up with the pace. Considering the status of the league in team sports every week-end competition, the players can not recover adequately, the week-end training to be done at the weekend of training to increase the sudden training load as a result of the desire to increase the risk of injury to players increases. The monitoring of the training load also includes methods that can be used in a wide range from minimum cost to maximum cost in order to optimize the performances of the players. In the current world of sport players need to optimize their athletic performance parameters before facing injury. Sports scientists, strength and conditioning coaches and athletic performance coaches try to optimize performance prior to injury while monitoring training loads in order to prevent injury, as players are affected negatively by the player while they are negatively affected. This review is intended to provide theoretical and practical information on the training load of sports scientists, conditioning coaches and athletic performance coaches in order to provide optimal performance levels in teams and individual players.

Keywords:Training Load, Internal Training Load, External Training Load, Sports Injuries.
\end{abstract}

\footnotetext{
+ Sorumlu Yazar: Zeki Akyıldız, zekiakyldz@ hotmail.com
} 


\section{GİRIŞ}

Sporcular üzerinde yapılan antrenmanların amacı, organizmanın fizyolojik adaptasyon özelliğinden faydalanıp organizmayı bir sonraki amaçlanan performansa ulaştırmaktır (Gabbett, 2016; Foster, 1998). Antrenmanlarda şiddet, süre, dinlenme aralı̆̆ 1 ve sıklığı gibi değişkenler sporcuyu adapte edilmek istenen amaca paralel olarak uygulatılmaktadır (Gabbett, 2016; Cardinale ve Varley 2017; Hulin ve ark., 2018). Antrenmanlarda oluşturulan streslere karşı vücut üzerindeki adaptasyon pozitif yönde olduğunda sporcuların performanslarının artırıldığı bilinmektedir (Malone ve ark., 2018).

Antrenman programları, insanların yapısal olarak adaptasyon özelliklerine dayanmasından dolayı aşamalı olarak aşırı yük kavramına dayanmaktadır (Bourdon ve ark., 2017). Antrenman programları sadece uygun süreci tanımlamak için değil aynı zamanda antrenman dozunu kişiselleştirmek ve en üst düzeye çıkartmak için kullanılan yöntemler arasındadır (Hulin ve ark., 2018). Antrenman faaliyetleri ve egzersiz programları, çeşitli biyolojik sistemlerin biçim ve işlevlerinde iyileşmelere yol açan çeşitli fizyolojik tepkileri tetikleyebilen uyaranların üretilmesi amacıyla tasarlanmaktadır. Antrenman, vücut bağışıklığını değiştirebileceği ve stres ortaya çıkartan çeşitli antrenmanlara karşı cevap veren çeşitli fizyolojik yapıları etkileyebileceği kabul görmüş bir kavramdır (Foster ve ark., 2017). İyi tasarlanmış bir antrenman programının sonucu, insan performansında iyileşmelere yol açan, hedef fizyolojik sistemlerin yapısında ve işlevinde gelişmedir. Bununla birlikte, antrenmanda kötü tasarlanan ve uygun olmayan bir ilerlemenin sonucu, sağlık bozukluğu, adaptasyon bozukluğu, hormonal profilde değişiklik ve tipik olarak düşük performans ile sonuçlanabilir (Cardinale ve Varley ,2017).

İnsan organizmasının karmaşık yapısının antrenmanlara verdiği tepkileri detaylandırıp pozitif ve negatif tepkileri anlayabilmek oldukça zordur, fakat antrenmanlara verilen tepkilerin detaylarıyla anlaşılabilmesi için son yıllarda oldukça fazla sayıda çalışma yapılmıştır (McCaskie, 2018). Sporculara yaptırılan antrenmanların amaçları daha önceden bilinmektedir fakat amaçlanan antrenmana sporcunun vücudunun ne derece tepki vereceği kesin olarak tahmin edilememektedir. Tüm organizmaların strese verdiği cevaplar farklılık gösterdiği için sporcuların adaptasyonlarının incelenmesi esnasında bireysel farklılıkların göz önünde bulundurularak değerlendirmeleri gerektiği düşünülmektedir (Collette, 2018). Sporcuların antrenmanlarının amacına yönelik yön verilmesi ve bu esnada sporcuların sağlıklı bir şekilde performansının arıtılıp aynı seviyede korunabilmesi için antrenman yükünün takibi spor bilimciler tarafından geliştirilmiştir. 
Antrenörlerin en yüksek performansa ulaşmak için gereken optimum antrenman miktarını belirlemede antrenman yükü takibi önemli bir yöntem haline gelmiştir (Foster, 1998).

Atletik performansın takibi ve antrenman yükünün takibi geçen yüzyılda kullanılmaya başlanmıştır (Foster ve ark., 2017). İskandinav bilim adamları Hannes Kolehmainen ve Paavo Nurmi olimpik koşucular üzerinde atletik takip yöntemleri kullanmaya başladığı bilinmektedir. Sporcu takibinin çağdaş kullanımı 1930'ların sonlarına doğru interval antrenmanlarda Alman Coach Woldemar Gerschler ve doktor Herbert Reindell tarafindan nabız ve dinlenme aralıkları izlenerek kullanılmaya başlanmıştır. Antrenmanların anlık etkisini ölçümlemek için AZD (Algılanan zorluk şiddeti) metodu geliştirilmiştir (Borg, 1982). Sporcu takibi 1980’lere gelindiğinde gaz analizörleri ve nabız bantlarının yardımıyla daha detaylı bir hale gelmiş ve iç yükler Banister, Karvonen gibi bilim insanları tarafından ele alınıp çeşitli formüller geliştirilmeye başlanmıştır. Eric Banister tarafından aynı dönemlerde TRIMP (Training Impulse) geliştirilmiştir (Banister, 1991).

Antrenman yükü ölçümleri iç veya dış olarak kategorize edilebilir. İç antrenman yükleri, antrenman veya müsabaka sırasında sporcuya uygulanan göreceli biyolojik (hem fizyolojik hem psikolojik) stresörler olarak tanımlanmaktadır. Kalp yükü, kan laktatı, oksijen tüketimi ve algılanan zorluk dereceleri (AZD) gibi ölçüler iç yükü değerlendirmek için sıklıkla kullanılır. Diğer taraftan, dış antrenman yükleri, sporcu tarafından antrenman veya müsabaka sırasında gerçekleştirilen çalışmanın objektif ölçümleridir ve iç yüklerinden bağımsız olarak değerlendirilir. Yaygın dış yük ölçümleri; güç çıkışı, hız, hızlanma, zaman-hareket analizi, global konumlandırma sistemi (GPS) parametreleri ve ivme ölçerden türetilen parametrelerdir. Sporcu antrenman yükünü ve tepkilerini takip için kullanılan bazı yaygın iç yük yöntemlerinin özeti ve değerlendirmesi Tablo 1'de, diş yük yöntemlerinin özeti ve değerlendirmesi Tablo 2'de sunulmuştur. Antrenman yüküne entegre yaklaşımlar da önemlidir ve bu nedenle antrenmana tepki olarak ortaya çıkan streslere daha detaylı bakış sağlamak için iç ve dış antrenman yükleri birlikte kullanılmalıdır (Bourdon ve ark., 2017; Gabbett, 2016). Örneğin, aynı antrenmanı farklı günlerde tekrarlayan sporcular, aynı süre içinde aynı güç çıkışını yani aynı dış yükü koruyabilirler, ancak durumlarına bağlı olarak oldukça farklı iç yükler (kalp hızı, kan laktatı, RPE, vb.) yaşayabilirler. Yorgunluk, duygusal rahatsızlıklar, yeni antrenman planlama tarihi veya hastalık bu iç ve dış yüklerden elde edilen parametrelerin değişkenlik göstermesini sağlamaktadır. İç ve dış yüklerin ayrı ayrı değerlendirilmesi sporcunun toparlanma kalitesini belirlemede yardımcı olabilir (Halson, 2014). 
Tablo 1. Sporcularda iç yükü görüntülenmesinde yaygın olarak kullanılan bazı yöntemlerin özeti ve değerlendirilmesi

\begin{tabular}{|c|c|c|c|c|c|c|c|c|c|}
\hline Metot & Maliyet & $\begin{array}{l}\text { Donanım } \\
\text { İhtiyac1 }\end{array}$ & $\begin{array}{l}\text { Yazılım } \\
\text { İhtiyacı }\end{array}$ & $\begin{array}{l}\text { Kullanım } \\
\text { Kolaylığ }\end{array}$ & Geçerlilik & Güvenirlilik & $\begin{array}{l}\text { Yorumlama } \\
\text { için } \\
\text { Kullanımı }\end{array}$ & $\begin{array}{l}\text { Antrenman } \\
\text { için } \\
\text { Kullanımı }\end{array}$ & Değişkenler \\
\hline \multicolumn{10}{|c|}{ İç Yük Ölçümleri } \\
\hline AZD & $\mathrm{D}$ & $\mathrm{H}$ & $\mathrm{E} / \mathrm{H}$ & $\mathrm{Y}$ & $\mathrm{O}-\mathrm{Y}$ & $\mathrm{O}-\mathrm{Y}$ & $\mathrm{E}$ & $\mathrm{E}$ & $\mathrm{AU}$ \\
\hline AAZD & $\mathrm{D}$ & $\mathrm{H}$ & $\mathrm{E} / \mathrm{H}$ & $\mathrm{Y}$ & $\mathrm{O}-\mathrm{Y}$ & $\mathrm{O}-\mathrm{Y}$ & $E$ & $E$ & $\mathrm{AU}$ \\
\hline TRIMP & D-O & $\mathrm{E}$ & $\mathrm{E}$ & $\mathrm{O}$ & $\mathrm{O}-\mathrm{Y}$ & $\mathrm{O}-\mathrm{Y}$ & $\mathrm{E}$ & $\mathrm{H}$ & $\mathrm{AU}$ \\
\hline Sağlık Anketleri & $\mathrm{D}$ & $\mathrm{H}$ & $\mathrm{E} / \mathrm{H}$ & $\mathrm{O} / \mathrm{Y}$ & $\mathrm{O}$ & $0-Y$ & $\mathrm{E}$ & $\mathrm{E} / \mathrm{H}$ & $\mathrm{AU}$ \\
\hline $\begin{array}{l}\text { Psikolojik } \\
\text { Envanterler }\end{array}$ & D-O & $\mathrm{H}$ & $\mathrm{E} / \mathrm{H}$ & $\mathrm{O} / \mathrm{Y}$ & $\mathrm{O} / \mathrm{Y}$ & $0 / \mathrm{Y}$ & $\mathrm{E}$ & $\mathrm{E}$ & $\mathrm{AU}$ \\
\hline $\begin{array}{l}\text { Kalp Hızı } \\
\text { indeksleri }\end{array}$ & $\mathrm{D}-\mathrm{O}$ & $\mathrm{E}$ & $\mathrm{E}$ & $\mathrm{Y}$ & $\mathrm{Y}$ & $\mathrm{O} / \mathrm{Y}$ & $\mathrm{E}$ & $\mathrm{E}$ & $\begin{array}{l}\text { Nabız atışı } \\
\text { zaman içindeki } \\
\text { alanlar }\end{array}$ \\
\hline Oksijen Alımı & $\mathrm{Y}$ & $\mathrm{E}$ & $\mathrm{E}$ & $\mathrm{D}$ & $\mathrm{Y}$ & $\mathrm{Y}$ & $\mathrm{E}$ & $\mathrm{E}$ & $\begin{array}{l}\mathrm{VO}_{2}, \text { Metabolik } \\
\text { eşitlikler }\end{array}$ \\
\hline Kan Laktatı & $\mathrm{O}$ & $\mathrm{E}$ & $\mathrm{E} / \mathrm{H}$ & $\mathrm{O}$ & $\mathrm{Y}$ & $\mathrm{Y}$ & $\mathrm{E}$ & $\mathrm{E}$ & Birikme \\
\hline Biokimyasal & $\mathrm{O}-\mathrm{Y}$ & $\mathrm{E}$ & $\mathrm{E} / \mathrm{H}$ & $\mathrm{D}$ & $\mathrm{Y}$ & $\mathrm{O}-\mathrm{Y}$ & $\mathrm{E}$ & $\mathrm{E}$ & Birikme, Hacim \\
\hline
\end{tabular}

Kısaltmalar: D, düşük; O, Orta; Y, Yüksek; E, Evet; H, Hayır; AU, Arbitrary units (keyfi birimler);AZD, Algılanana Zorluk Derecesi; AAZD, Antrenmanda Algilanan Zorluk Derecesi, Trimp; Training Impulse (Antrenman Etkisi) (Bourdon ve ark., 2017).

Tablo 2. Sporcularda diş yükü görüntülenmesinde yaygın olarak kullanılan bazı yöntemlerin özeti ve değerlendirilmesi

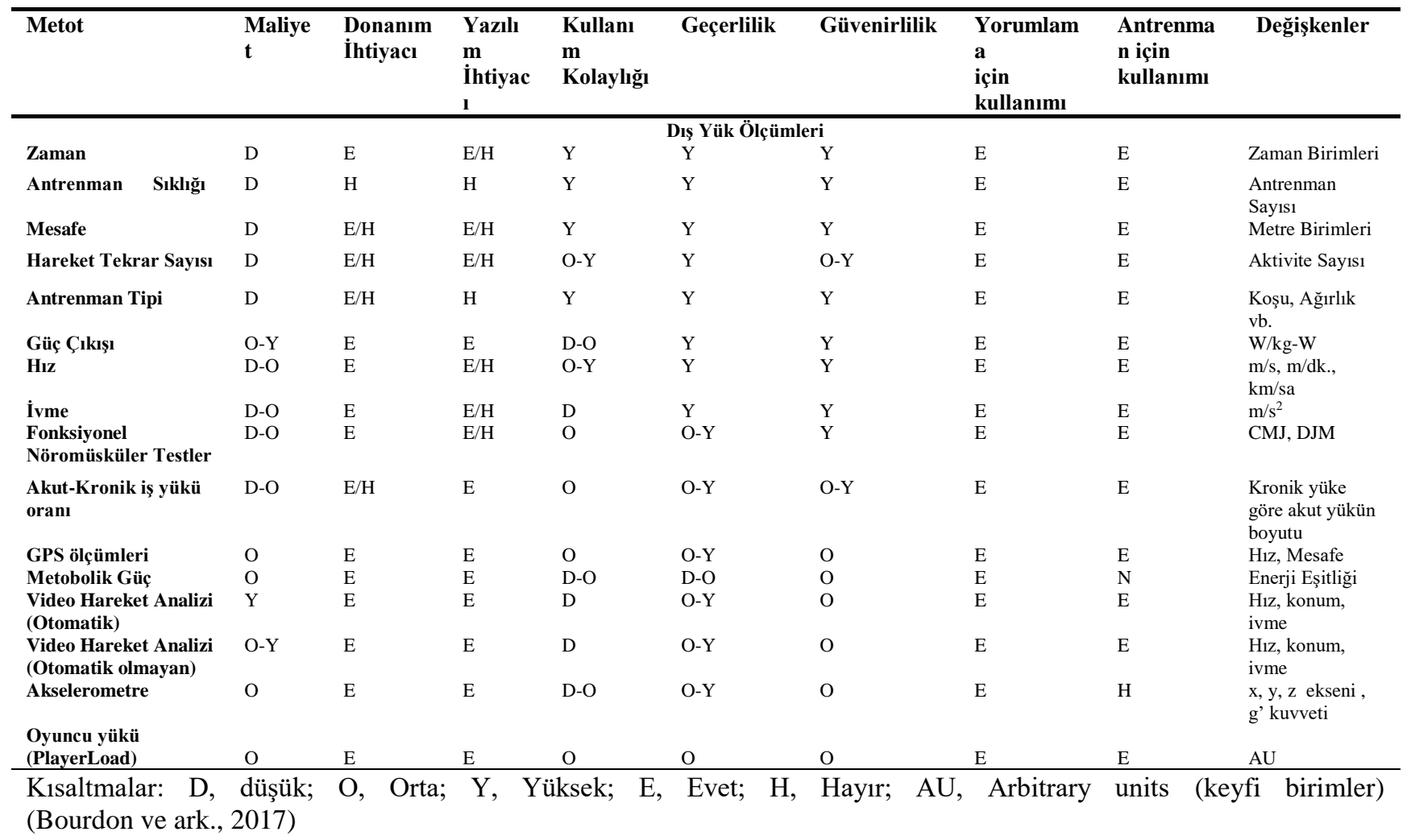

Antrenman programının optimizasyonu, sporcunun ne yaptığııı ve yapılan antrenman faaliyetlerine nasıl tepki verdiklerini yönetmede etkilidir. Sporcuların vücutlarının antrenmana verdiği tepkiler sporcunun antrenman yükünün ölçümüyle gerçekleştirilmektedir. Son birkaç 
yıldır, çeşitli çalışmalarda çeşitli antrenman yükü paradigmalarının etkilerini anlamamızı geliştirmek için çok sayıda çalışma yapılmıştır ancak, antrenman faaliyetlerinin takibi açısından yararlı kanıtlar olmasına rağmen antrenman yükünün takibinde sonuçların yorumlanması, antrenörlerin elde edilen verileri sahaya uygulayabilecek yeterlilikte olmaması ve finansal yetersizlikler gibi engellerle karşılaşılmaktadır. Son zamanlarda yapılan araştırmalar, sporcular tarafından antrenman ve müsabaka ortamında giyilebilen hareket ölçüm sistemlerinin (IMU) erişilebilirliği sayesinde çoğunlukla dış yük çalışmalarının egemenliğindedir. Maliyet ve çalışma dizaynındaki zorluklar nedeniyle AZD 'de haricinde iç yük üzerine boylamsal çalışmalarda eksiklik vardır.

\section{Antrenman Yükü Takip Yöntemleri}

Antrenman yükü takibi takım sporlarında ve bireysel sporlarda kullanılmaya elverişlidir ancak son zamanlarda takım sporlarında oyuncuların sakatlık maliyetleri göz ününde bulundurulduğunda antrenman yükünün takibine takım sporlarında daha da çok önem verilmektedir (Brito ve ark., 2016). Takım sporlarında antrenman yükü takibinin öncüsü rugby sporcuları olmuş, bununla birlikte futbol dünyasında da çeşitli birçok takım, antrenman periyotlarını antrenman yükü parametrelerine göre organize etmektedirler (Fox ve ark., 2018). Teknolojik gelişmelerle antrenman yükünün takibindeki gelişmeler paralellik göstermektedir ve bu teknolojik gelişmeler spor dünyasında saha uygulamalarında pratik olarak uygulanılabilecek giyilebilir teknolojiler olarak geliştirilmektedir (Cardinale ve Varley, 2017). Her ne kadar, antrenmana karşı kondisyon ve yorgunluk yanıtlarını doğru bir şekilde hesaplayabilen tek ve kesin bir belirteç olmasa da son yıllarda dayanıklılık antrenmanı ve müsabaka yüklerini ölçmek için ekipman ve yöntemlerin geliştirilmesi ve onaylanması dikkate değer gelişmeler göstermiştir. Bu tür sistemlerin temel özellikleri, kullanım kolaylığı, sezgisel tasarım, verimli sonuç raporlaması, uzaktan kullanabilme yeteneği, verilerin basit sonuçlara dönüştürülebilmesi, farklı sporlar için uyumluluk, anlamlı değişimi basit ve etkili bir şekilde tanımlama becerisini içermeleri, bilişsel işlev ve hem bireysel hem de grup yanıtları sağlama yeteneğidir (Gabbett, 2016; Cardinale ve Varley, 2017; Hulin ve ark., 2018).Teknolojik gelişmelere sahip olmak, takımların bütçeleri ve olanaklarıyla sınırlı olduğu için maliyeti oldukça düşük olan çeşitli takip yöntemleri de geliştirilmiştir. Antrenman yükü takibi iç ve dış antrenman yükü ölçüm yöntemleri olarak değerlendirilmektedir (Akubat ve ark., 2018). 


\section{Dış Yük Takibi}

Dış yükün ölçümleri, kat edilen mesafe, sporcunun hızı ve antrenman süresi gibi faktörlere bağlıdır. Mikro teknolojinin sporda (güç sayaçları, global konumlandırma sistemi [GPS] cihazları, ivmeölçerler) artan kullanımı, uygulayıcıların sporculardaki dış yükü antrenman ve müsabaka sırasında gerçek zamanlı olarak takip etmelerinin sağlamışıtır (McGuigan, 2017). Dış antrenman yükü, ağırlık kaldırma sayısı, koşu esnasında toplam kat edilen mesafeler ve antrenman esnasında ya da müsabakada gerçekleştirilen sprintlerin, vuruşların ve sıçramaların sayısı gibi şeyleri ifade eder. Bu bilgi olmadan, uygulayıcı uygun yükleri belirleyemez. GPS, ivmeölçer ve güç ölçerler gibi teknolojiler artık dış yükün objektif ölçümlerini sağlamak için yaygın olarak kullanılmaktadır. $\mathrm{Bu}$ tür teknolojiye erişimi olmayan uygulayıcılar, sporcunun antrenmanlarda neler yaptığını (örneğin, setler, tekrarlar, yük, aralıkların sayısı, mesafe, süre, uzunluk ve toparlanma periyotları) not edebilir. Ancak, bu önlemler sporcunun antrenman yüküne nasıl tepki verdiği hakkında bilgi vermez. Bu nedenle iç yük ölçümlerinin de izlenmesi önemlidir (Sparks ve ark., 2017).

\section{Antrenman Yükü Takibinde GPS Ölçümleri}

GPS sistemlerinin ilk kullanımı Amerikan ordusu tarafından yön tayini yapabilmek ve savaş ortamında konum tespiti yapıp doğru yöne saldırılarda bulunabilmek için kullanılmıştır (Hewitt, 2016). Silah sanayisinde 1973 yilından beri kullanılmakta olan bu cihazların ilerleyen yıllarda kullanım alanları artmıştır ve daha gelişmiş, teknolojilerin silah sanayisinde kullanılması ile beraber GPS sistemleri sivil hayata girmeye başlamıştır (Hewitt, 2016).

Sporcular üzerinde GPS sisteminin kullanımı Avustralyalı bilim adamları tarafından geliştirilmiştir. Takım sporlarına GPS sisteminin uyarlanması 2003 y1lında Gpsports firması tarafından yapılmıştır (Edgecomb ve ark., 2006). 2003 yılının teknolojisi ile günümüz teknolojisinin arasındaki farklar GPS sistemlerine de yansımıştır, 2003 yılından bu yana GPS sistemleri üzerinde geliştirilen farklı veri formasyonları vardır ve hala geliştirmeye devam etmektedir. Günümüzde Gpsports, Catapult ve Statsports gibi ana GPS firmaları çeşitli branşlara hizmet etmektedir, Futbolun dışında genellikle rugby, buz hokeyi, çim hokeyi ve Amerikan futbolcuları üzerinde GPS sistemleri kullanmaktadır (Gabbett, 2010). Spor bilimciler ve antrenörler tarafından günümüzde çok yaygın bir şekilde GPS sistemleri kullanmaktadır, bunun nedeni GPS sisteminden alınan ve sporcunun antrenmanına yön veren yüzlerce veridir. Sporcuların müsabakalarda ve antrenmanlarda maruz kaldığı akut ve kronik yükleri, sakatlık 
analizlerini, fizyolojik olarak kişinin performansını takip edebilmek ve sporculara yönelik data analizi yapabilmek için spor bilimciler tarafından GPS sisteminden elde veriler yaygın bir şekilde kullanılmaktadır. Diğer analiz yöntemlerine göre taşınabilir olması, giyilebilir olması ve kullanışlı yazılımlara sahip olması ön plana çıkmaktadır (Hewitt, 2016).

GPS'in takım sporlarında özelliklede futbolda çeşitli parametreleri detaylı incelemek için kullanımı yaygındır. Antrenmanlarda ve müsabakalarda oyuncuların sırt bölgelerinde bulunan hazneye, vücudun hareketleri dışında hareketlilik göstermeyeceği şekilde GPS üniteleri yerleştirilir ve oyuncuların takipleri bu şekilde sağlanmış olur. Teknik olarak uydu ile $1 \mathrm{~Hz}, 5 \mathrm{~Hz}$, $10 \mathrm{~Hz}, 15 \mathrm{~Hz}$ ve $20 \mathrm{~Hz}$ gibi farklı hızlarda gerçek zamanlı, hem fizyolojik hem de kinematik olarak veri aktarımı sağlayabilen, kişilerin kalp atım hızlarını, kat edilen mesafeyi, ivmelenmeyi, yavaşlamayı, tekrarlanan sprint sayısını, oyun sahasının farklı alanlarında bulunma oranlarını, tüketilen kalori miktarını, kişisel farklılık gösteren nabız alanlarını, koşu sırasındaki hızlarını ve farklı hız aralıklarında kat edilen mesafeleri, farklı hız aralıklarında geçirilen süreleri, sprint hareketlerindeki üretilen güç miktarlarını, sporcuların hareket esnasındaki koşu asimetrilerini ve tüm veriler arasındaki ilişkiyi sergileyen donanımı ve kendine ait hem yazılım sistemi, hem de mobil cihazlarda online kullanılabilmesi için mobil uygulama alt yapılı çalışabilen ekipmanlardır. (Akyıldız ve Ocak, 2018).

GPS sistem uzaydaki uydularla haberleşme sistemini kullanarak yön ve pozisyon tespitini yaparak, dünya üzerindeki konumu göstermektedir. GPS sistem insan deneylerinde hayvan deneylerinde biyomekanik deneylerde ve insanların yapmış, oldukları hareketlerin şiddetini belirleyen deneylerde kullanılmaktadır (Alemdaroğlu, 2011; Aslan ve ark., 2012). Takım sporlarında dış antrenman yükü, antrenmanlarda ve müsabakalarda düzenli olarak GPS kullanılarak rutin olarak ölçülür (Bourdon ve ark., 2017). Bu ekipmanlar spor biliminde büyük yenilikler ortaya koyan giyilebilir teknolojinin önde gelen etkili örnekleridir. Ünitelerin müsabakalarda oyunculara takılması Dünya futbol federasyonu (FIFA) tarafindan kabul görmüştür, bu nedenle oyuncuların haftalık planlamalarına müsabaka verilerinin dahil edilip antrenman programlarının daha hassas oluşturulabilmesi için müsabakadaki iç ve dış yükler bu ünitelerden elde edilmektedir.

GPS cihazları, dış yükü ölçmek için kullanılabilecek bir dizi metrik sağlamak üzere çeşitli algoritmalar ve filtreler kullanılarak işlenen konum, hız ve ivme ölçümünü yapar (Cummins ve ark., 2013). İvmeölçerler, 10 yılı aşkın bir süredir hareketin miktarını belirlemek için 
kullanılmıştır. Akıllı telefonlar, giyilebilir fitness cihazları ve bireysel hareket ivmeölçer sensörleri gibi teknolojilerde artık yaygındır. İvmeölçerler, vücuda uygulanan genel dış yükü tahmin etmek için kullanılabilecek bir hızlanma ölçüsü sağlarlar (Boyd ve ark., 2011). Bu sistemde çarpışmalardan, ayak hareketlerinden ve ivme ölçer tabanlı algoritmalardan dış yük tespit edildiği için hız ve mesafe tabanlı metriklere göre daha hassas ve detaylı sonuçları almak mümkündür (Boyd ve ark., 2011). GPS kullanırken hesaba katılmayan diğer hareketler ivme ölçer sayesinde hesaplanabilir. Sporda kullanılan hemen tüm GPS cihazları üç eksenli bir ivmeölçer içerir. Cihazlar, sırasıyla yönü, yönelimi ve açısal hareketi ölçen bir manyetometre ve jiroskop da içerebilir (Gabbett, 2013). Buna ek sensörlerden gelen veriler, gelişmiş hareket modellerini hesaplamak için entegre edilebilir ve iç mekân sporlarındaki yükü ölçmek için kullanılabilir.

GPS'den türetilen tipik olarak diş yük ölçümleri, bir sporcunun çeşitli hız veya ivme eşiklerinde yapmış olduğu hareket sayılarını veya mesafeyi de içerebilir (Akenhead ve ark., 2014). Dış yük ölçümleri, analiz sırasında ya da diğer spor uygulayıcıları ile iletişim sırasında sıklıkla yanlış yorumlanır. Örneğin, sprint mesafesi tipik olarak bir sporcunun sprint-hız eşiğinden (yani, $7 \mathrm{~m} / \mathrm{s}$ ) daha hızlı hareket ettiğini belirtir. Bu, sprintin statik bir başlangıçtan başladığı antrenman ve test sırasında bir sprintin düşünüldüğünden farklıdır. Benzer şekilde, hızlanma girişimi, sporcunun belirli bir hızlanma hızının üzerinde harcadığı süredir. Hızlanma oranı maksimum ivmelenmeden sonra hızla azalmaktadır, hızlanma sporcunun sadece ilk bir veya iki adımına işaret edebilir. İvmelenme ve hız parametreleri hareketler içinde farklılık göstermektedir. Bu ölçütleri, kullanmadan önce tam olarak antrenörlere ve uygulayıcılara açıklamak önemlidir çünkü, giyilebilir teknolojinin kullanıcılarına sunulan yeni metriklerin sayısında giderek bir artış olduğu görülmektedir.

\section{Mesafe ve Hız Ölçümleri}

Toplam mesafe, giyilebilir teknolojiyi kullanarak yapılan en yaygın DIŞ yük ölçümüdür. Bu ölçüm GPS verileri kullanılarak sağlanır ve konumsal farklılaşma veya Doppler kaydırma hızının integrali kullanılarak hesaplanır. Tüm üreticiler seçtikleri yöntemi açıklamamasına rağmen, iki önemli GPS üreticisi (Catapult Sports ve GPSports) mesafeyi hesaplamak için konumsal farklılaşma kullandıklarını bildirmektedirler. Sıklıkla, kapsanan mesafe belirli hız eşiklerine göre raporlanır ve düşük hızlı koşu, yüksek hızlı koşu ve sprint eşiğinin belirlenmesi yaygındır (Hackney, 2013). 
GPS cihazı, ya zamanla mesafedeki değişiklikten türetilen hızı hesaplar (konumsal farklılaşma ile belirlenir) ya da Doppler yöntemini kullanarak hesaplamalarını yapar. Doppler daha fazla hassasiyete sahip olup daha az hata payına sahip olduğu için genellikle üreticiler tarafından kullanılmaktadır (Townshend ve ark., 2008). Ham GPS hızı verileri, üreticiye göre değişecek olan filtreleme teknikleri kullanılarak daha fazla işlenebilir. Farklı filtreleme teknikleri, hız çıkışını önemli ölçüde değiştirebilir ve tüm üreticiler tarafından kullanıcılara bildirilmez. Uzaklık ve hız verisinden elde edilen dış yük ölçümleri, belirli hız eşiklerinde kat edilen mesafeyi ve belirli hız aralıklarında gerçekleşen aktivite sayısını (Sprint Sayısı) içerir.

Araştırmacılar ve uygulayıcılar genellikle yüksek hızda kat edilen mesafe ve sprint sayısına odaklanmaktadırlar çünkü sporcunun üstlendiği en zor ve önemli hareket olduğu düşünülmektedir. Bununla birlikte, yüksek hızlı koşu, yüksek yoğunluklu aktivite olarak yorumlanmamalıdır, çünkü bu, sporcuya uygulanan dış yükün tam bir yansıması değildir (Abt ve Lovell, 2009). Yüksek yoğunluklu aktiviteler arasında sıçramalar, ivmeler, yavaşlama, yön değişimi ve ikili mücadeleler de da bulunabilir (Osgnach ve ark., 2010).

\section{Hızlanmalar}

Yapısı gereği aralıklı olan sporlarda ani hızlanmalar sıklıkla görülmektedir. Futbol oyununun içeriği ele alındığında oyuncuların oyun içerisinde yüzlerce hızlanma ve yavaşlama gösterdiği buna karşılık hızlanmaları fazla olan sporcuların kat ettiği mesafelerin ya da yüksek

hızlarda kat ettiği mesafelerin düştüğü gözlemlenmektedir (Sparks ve ark., 2017). Dış yük takibinde hızlanmalar kullanıldığında, hızlanma ve yavaşlama esnasında iç yüklere yansımayan, sadece teknolojik takip sistemleriyle gözlemlenip objektif verilerle tespit edilebilen parametreler elde edilebilmektedir. Antrenman yükü takibinde hızlanmaların hesaplamalara dâhil edilmesi büyük farklılıklar ortaya çıkartıp daha doğru sonuçlara ulaşılmasını sağlamaktadır.

Hızlanmalar esnasında sabit hız hareketlerine göre daha fazla enerji ihtiyacı vardır (Di Prampero ve ark., 2005). Sabit başlangıcı olan maksimum 5 sn'lik bir sprint sırasında, toplam işin\%50'si ilk 1.5 s. içinde elde edilir ve bu ortalama güç çıkışından \%40 daha fazladır, zirve güç çıkışı sadece 0.5s sonra elde edilmektedir. (Di Prampero ve ark., 2005). Böylece, bir başlangıçtan itibaren, en zorlu hareketler, sürat eşiğine ulaşılmadan önce gerçekleştirilir, dahası düşük bir hızdan ivme elde edildiğinde, daha yüksek sabit bir hız sağlamak için gereken güç çıkışına eş olabilir hatta daha fazla olabilir (Osgnach ve ark., 2010). Hızlanma metabolik olarak zorlu bir iştir, 
ancak yüksek bir hızda meydana gelmesi gerekmez. İvmelenmelerin enerji gereksinimleri düşünüldüğünde, dışsal yükün yalnızca mesafe ve hız ölçümlerine dayalı olarak ölçülmesi durumunda, sporcular tarafından üstlenilen gerçek yüksek yoğunluklu çalışmaların göz ardı edileceği düşündürmektedir. Tipik olarak, ivmelenmelerin sayısı veya spesifik ivme eşiklerinde kapsanan mesafe dış yük olarak kullanılır. Ancak, mevcut teknolojinin sınırlamaları göz önüne alındığında bu verileri yorumlarken dikkatli olunmalıdır (Cardinale ve Varley, 2017).

\section{Akselerometre Tabanlı Ölçümler}

Akselerometreler, GPS tabanlı metriklerin sınırlamalarının üstesinden gelebilecek fiziksel aktivite ölçümü sağlamaktadırlar. Bu ölçümler; hızlanma, yavaşlama, yön değişikliği, çarpışma ve ayak etkilerinden kaynaklanan toplam stresi gösteren, vücut üzerindeki toplam yükü ölçmemize yardımcı olan etkili bir araştır (Bartlett ve ark., 2017). Cihazları üreten şirketlerin bu yükün nasıl hesaplandığı konusunda küçük farkl1lıkları olabilmektedir ancak tipik olarak üç eksenli bir ivmeölçer kullanılarak ölçülen her üç hareket düzleminde hızlanma, yavaşlama, sıçrama ve yön değiştirme hareketlerinin toplamıdır. Bu sisteme örnek olarak Catapult firması tarafından kullanılan X, Y ve Z eksenlerindeki ivmenin anlık değişim hızının toplamının karekökünün 100’e bölünerek hesaplandığı "PlayerLoad" metriği gösterilmektedir (Cummins ve ark., 2013).

GPS ölçümleri uydu sinyalinin kalitesine bağlıyken, bu yük ölçüleri sadece ivme verilerinden hesaplanır ve bu nedenle iç mekanlarda veya zayıf sinyal kalitesine sahip alanlarda (örneğin iç veya yüksek duvarlı stadyumlar) toplanabilir. Antrenman sırasında dış yükü ölçmek için 'PlayerLoad' ölçümlerini kullanan araştırmalar, toplam mesafeyi kapsayacak şekilde güçlü bir ilişkiye sahip olduğunu bulmuştur (Sparks, 2017). Uygulamacıların, GPS mevcut olmadığında (örn. Kapalı alan) toplam mesafe ölçümleri için PlayerLoad ölçümlerini birer destekçi araç olarak kullanılabileceği önerilmiştir (Polglaze ve ark., 2015). Akselerometredeki dış yük değerleri bireysel bir niteliktedir bu nedenle, uygulayıcılarının karşılaştırmaları sporcular arasında değil, sporcunun kendi parametrelerindeki değişimleriyle olmalıdır.

\section{Dış Yük Takibinde Kullanılan Araçların Geçerliliği ve Güvenirliği}

Sporlar için mevcut olan giyilebilir cihazların sayısı arttıkça, antrenman uygulamalarını şekillendirmek için teknolojik cihazların güvenilirlik ve geçerliliklerini anlamakta sorgulanması esas olan kurallar arasındandır. Sporcuların antrenmanları ile ilgili kararlar, antrenman yükündeki 
küçük dalgalanmalara bağlı olabilir, bu nedenle, gerçek değişim ve ölçüm hatası arasında ayrım yapmak için hassasiyet çok önemlidir (Buchheit ve ark., 2016).

Cihazlar üretildikten sonra üretici doğrulaması nadiren yapılmaktadır, bu nedenle her bir cihaz ve cihaz metriği için hatayı anlamak, böylece dış yük değişkenleri hakkında doğru varsayımların yapılabilmesi için cihazların doğrulanması gereklidir. Önemli sayıda çalışma, sporda kullanımları için giyilebilir teknolojinin geçerliliğini ve güvenilirliğini değerlendirmiştir (Scott ve ark., 2016).

Ölçme mesafesi ve hızı için GPS cihazlarının geçerliliğii, daha yüksek örnekleme sıklığıyla gelişmektedir (Rampinini ve ark., 2015). İyileştirmeler, mikro teknolojik ve sinyal işleme algoritmalarındaki gelişmelerden de kaynaklanabilir. GPS sistemlerinden elde edilen verilerde yüksek hızlarda doğruluk oranının azaldığı görülmüştür (Akenhead ve ark., 2014). Bununla birlikte, geçerlilik çalışmaları, yüksek hızın değerlendirilmesinde statik bir başlangıçtan başlamak üzere koşu denemelerini içeren protokolleri sıklıkla kullanmıştır. Hızlanma ve yüksek hızlı koşu fazlarını izole eden çalışmalarda, hızlanma arttıkça GPS doğruluğu azalmaktadır (Varley ve ark., 2012). Örneğin, GPS'in sabit yüksek hızlarda $\left(5-8 \mathrm{~ms}^{-1}\right)$, düşük sabit hızlara (1-3 ms $\left.{ }^{-1}\right)$, kıyasla ölçümler arasında sırasıyla \%3 ve \%8 daha düşük bir varyasyon katsayısına sahip olduğu bulunmuştur (Varley ve ark., 2012). Benzer şekilde, geçerlilik çalışmalarında GPS den elde edilen parametrelerin daha uzun mesafelerde iyileşme gösterdiği fakat ivme evresinde nispeten azaldığı görülmüştür (Jennings ve ark., 2010). Bu durum yön değişikliği hareketleri ve kısa patlayıcı hareketler gibi hızda hızlı değişiklikler gerektiren hareketler için artan hataların olabileceğini açıklamaktadır.

Giyilebilir teknolojinin geçerliliği ve güvenilirliği teknolojik gelişmeler ile paralellik göstermektedir. Geçerlilik araştırması genellikle yeni teknolojinin piyasaya sürülmesinden sonra gerçekleştirildiği için, uygulayıcıların bu bilgi mevcut olmadan önce cihazları kullanması muhtemeldir. Ne yazık ki, her yeni cihaz sürümü, yükseltmesi ve ürün yazılımı veya yazılım güncellemelerinden sonra oluşabilecek veri işlemlerinde yapılan değişikliklerinin ardından doğrulama gereklidir. Sporcu takip yeteneği, zamanla antrenman yükü ölçümlerinde değişikliklerin yapılmasını gerektirir. Bu nedenle, uygulayıcıların mümkün olan yerlerde veri toplama, işleme ve analizde tutarlılık sağlamaları tavsiye edilir. Uygulayıcılar, sezonun sonuna kadar cihaz ve sistem güncellemelerini geciktirmek isteyebilirler. Geriye dönük veriler yeniden işlenebiliyorsa, bu her yeni sezon için karşılaştırılabilir veriler sağlayabilir. Bu tutarlılık, sporcuları 
değerlendirmek için kullanılan dış yük ölçümlerinin güvenilirliğini artıracaktır (Cardinale ve Varley, 2017).

\section{İç Yük Takibi}

İç yük, antrenman sırasında sporcu üzerindeki fizyolojik strese işaret eder, bu durumda antrenman programına adaptasyonu büyük ölçüde belirler. İç yük ölçümleri için Şekil 1' de gösterildiği gibi çeşitli yöntem ve teknolojik ekipmanlar kullanılmaktadır (Gabbett, 2016; Alemdaroğlu ve Köklü, 2017). Sporcuları izlerken, uygulayıcıların hem dış hem de iç yükü dikkate almaları gerekmektedir. Dış yüke yanıtlarda bireysel farklılıklar olmasına rağmen dış ölçütler kullanılarak antrenman öngörülmüştür (Sparks ve ark., 2017). Örneğin, bir atlet iki bisiklet testi sırasında aynı oranda watt (Dış yük) üretebilir ancak iki antrenman sırasında farklı test sonuçları elde edilebilir ve iki testte farklı kalp atış hızı yanıtları (iç yük) olabilir (McGuigan, 2017). Araştırma ayrıca sporcuların aynı dış iş yüküne farklı iç tepkileri yaşayabileceklerini de göstermektedir (Sparks ve ark., 2017). Bir uygulayıcı, iç yükteki bireysel farklılıkları göz önünde bulundurmadan bir grup sporcu için diş yükler belirlediğinde, yorgunluk ve antrenmana adaptasyonla ilgi sorunlarla karşılaşabilir. Uygulayıcılar, dış ve iç yük arasındaki farkı anlamalıdırlar. Dış yük ölçümleri, antrenman ve müsabaka sırasında sporcunun fizyolojik stresinin doğru bir göstergesi olmayabilir. Sporcuların fiziksel uygunluk düzeyleri sporcuya uygulanan psikolojik ve fizyolojik yükü içeren iç yük ile ilgilidir. Dış yükün izlenmesi, sporcunun antrenmana nasıl uyum sağladığına dair önemli bilgiler sunar ancak yetersiz kalmaktadır. Kalp hızı ve AZD gibi ölçümler, iç yük takibinin en yaygın yöntemidir (Foster ve ark., 2017). Uygulayıcılar ayrıca, öznel sağlık derecelendirmelerini laktat ölçümü, Vo2 ölçümleri ve fizyolojik kan belirleyicilerini de iç yük ölçümlerini belirlemek için kullanmaktadırlar (Cardinale ve Varley, 2017). 


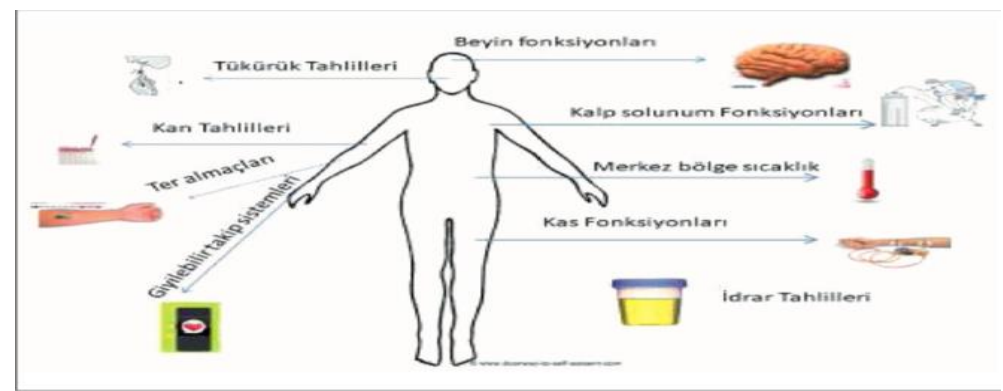

Şekil 1. İç Yük Ölçüm Yöntemleri (Gabbett, 2016; Alemdaroğlu ve Köklü, 2017)

\section{Antrenman Yükü Takibinde Psikolojik Ölçümler}

Toparlanma potansiyeli, egzersiz kapasitesi, zorlayıcı olmayan stres faktörleri ve stres toleransındaki bireysel farklılıklar, sporcuların aynı antrenman koşulları altında maruz kaldıkları farklı derecelerdeki tepkilerini açıklayabilir. Önemli olan sporcuları bireysel olarak değerlendirmek, düzenli olarak takip ve elde edilen verileri boylamsal olarak karşılaştırmaktır. Çalışmalar, psikolojik göstergelerin fizyolojik göstergelere göre daha hassas ve tutarlı olduğunu göstermiştir (Foster, 1998). Ayrıca, psikolojik ölçümler fizyolojik veya kan belirteçlerinden daha hızlı dakikalar içinde uygulanabilir ve raporlanabilir. Antrenmanlar da kullanılan ortak endeksler arasında, ruh hali durumunun profili (Profile of Mood State) ve onun türevleri olan AZD, AAZD sporcular için toparlanma-stres anketi kullanılmaktadır (Foster, 1998; Bourdon ve ark., 2017). Son zamanlarda, akut toparlanma ve stres ölçeği ve kısa versiyonu olan kısa toparlanma ve stres ölçeği spor uygulayıcılarının toparlanma ve stresini ölçmek için ekonomik, geçerli ve değişime duyarlı psikometrik bir araç talebinin karşılanması amacıyla geliştirilmiştir (Bourdon ve ark., 2017).

\section{Kardiyovasküler ve Solunum Ölçümleri}

Kalp atış hızı tepkilerinin antrenmanlarda ölçülmesi, iç yükün ölçülmesi için en erken örnektir. 20. yüzyılın başlarında elektrokardiyografinin icadı sonrasında, kalp atışı monitörlerinin gelişmesiyle, 1980'lerden bu yana egzersiz sırasında kalp atışı tespit edilebilmiştir. Yıllar boyunca, bu cihazların geçerliliğini ve güvenilirliğini değerlendirmek için çok sayıda çalışma yapılmış sonuç olarak kalp atım monitörü fiziksel aktiviteler sırasında hem geçerli hem de güvenilir bulunmuştur. Kalp atım monitörü kullanımı, sporcuların antrenman ve müsabakada yaşadıkları kardiyovasküler yükü ölçmek için çeşitli antrenman yükü indekslerinin geliştirilmesine izin vermiştir (Akubat ve ark., 2018). Kullanılan antrenman yükü endekslerinin çoğu, kalp atış hızının maksimalinin farklı aralıklarında geçirilen süreler ve $\mathrm{Vo}_{2}$ arasında belirli varsayımlar yapmaktadır. 
Artan testler sırasında $\mathrm{O} 2$ ve yoğunluk bölgelerini ve her bölgede harcanan süreyi maksimum kalp atış hızı yüzdesi olarak ifade eder ve bu tür yaklaşımları kullanarak antrenman yükünü ölçmek için çeşitli olasılıklar vardır. Son zamanlarda gögüsten kalp atım hızını görüntüleyen kayışların yerini, yakın kızıl ötesi spektroskopisi yöntemiyle nabız ve kas oksijenasyonunu değerlendirmek için ölçen teknolojik sistemler almaya başlamıştır (Gao ve ark., 2016). Sporcuların biyolojik parametrelerinin tüm maç ve antrenmanlarında spor bilimciler tarafından detaylı bir şekilde analiz edilmesinde teknolojinin gelişmesi olanak sağlamıştır (Cardinale ve Varley, 2017).

\section{Hormonal Parametreler}

Çeşitli egzersiz ve antrenman paradigmalarına akut ve kronik yanıtları karakterize edebilen bir dizi biyokimyasal, hormonal ve immünolojik belirteçler inceleyerek büyük miktarda araştırma yapılmıştır (Cardinale ve Varley, 2017). Hormonal ölçümlerin uygulanmasındaki sınırlamalar, ölçümlerin invazivliği ve antrenmana verilen hormonal tepkilerin belirlenmesinin maliyetinin fazla olmasıdır. Hormonal parametrelerin takibindeki bu sınırlılıklar nedeniyle oyuncular üzerinde boylamsal gözlemlerin yapılması zorlaşmaktadır. Bu nedenle, bu tür ölçümleri daha ucuz, daha erişilebilir ve daha az noninvaziv yapan ayrıca hızlı geri bildirim fırsatları sağlayan daha ileri teknolojik gelişmeler sayesinde çeşitli antrenman uygulamalarının etkilerine 1şık tutabilecek bir araştırma ve uygulama alanı olabileceğine inanılmaktadır. Sporda giyilebilir teknolojilerin gelişmesi laboratuvarda yapılan testlerin sahada gerçek zamanlı olarak uygulanmasına olanak sağlamaya başlamıştır. Oyuncuların ter, hız, nabız ve vücut ısısı gibi çeşitli analizleri gerçek zamanlı olarak antrenör ve spor bilimcilerle paylaşılmaktadır (Hooton ve ark., 2016). Bununla birlikte, bu tür yöntemler, sahadaki uygulamada hala tam olarak pratik değildir. Laboratuvar ekipmanı ve numuneleri işlemek için gerekli uzmanlık basit analitik süreçler ve erişilebilir ekipman geniş ölçüde mevcut olduğunda, bu tür tekniklerin gelecekteki uygulamaları sporda daha da gerçekleştirilebilir hale dönüşecektir. Giyilebilir çözümlerin sahaya uyarlanma aşamasındaki çalışmalar hızla gelişmektedir, insan derisinin cihazlarla donatılmasının fizibilitesi, birkaç laboratuvarın öncü çalışması ile yakın zamanda ortaya konmuştur (Kim ve ark., 2011, Schwartz ve ark., 2013). Genel olarak, daha ucuz ve daha detaylı teknolojiler ve yöntemler ortaya çıkıncaya kadar, antrenmana karşı biyolojik tepkileri anlamamız, spor bilimcilerin ve koçların sporcuların günlük aktivitelerini ve antrenman yükünü bu sistemlerden elde etmesiyle sınırlı kalacaktır. Bu nedenle, uygulayıcılar antrenman yükü takibinin biyokimyasal belirteçlerini tespit ederken yöntemlerin sınırlamaları, biyolojik ve bireysel değişkenliğini ve halihazırda nicel olarak ölçülen 
birçok parametrenin birçok değişken tarafından etkilenebileceğini dikkate alarak dikkatli bir şekilde kullanmalıdırlar.

\section{Nöromüsküler Parametreler}

Antrenman yükünün nöromüsküler parametrelerinin değerlendirilmesi, mevcut teknoloji tarafından bir ölçüde sınırlandırılmıştır. Son gelişmeler, egzersiz sırasında kas aktivitesini ölçebilen elektromiyografik (EMG) sensörlü spor giysilerini içermektedir (Finni ve ark., 2007). Sporcu ve sporcu olmayanlar üzerinde müsabaka ve antrenmanda EMG kullanımıyla ilgili çalışma ortaya koyulmuştur ancak yazarın bilgisine göre, bu tekniği kullanarak iç yük değerlendirmelerini sunan uzunlamasına bir çalışma yoktur (Montini ve ark., 2017). Bu tür teknolojilerin hantal ekipmanın yanı sıra engelleyici maliyetleri nedeniyle spor ortamında antrenörler tarafından pratik kullanımı kısıtlayıcıdır ancak nöromüsküler sistem fonksiyonlarını değerlendiren çeşitli testler ile akut ve kronik olarak reaksiyon zamanı, elektroensefalografi (EEG) yanıtları, dikey sıçramalarla nöromüsküler fonksiyon değerlendirmek mümkündür. Nöromüsküler parametreler için, bu alandaki teknoloji çok hızlı bir şekilde gelişmektedir ve atıcılık gibi spor aktiviteleri sırasında EEG ölçümlerine örnekleri bulunmaktadır (Cheron ve ark., 2016). EEG'nin beyin üzerindeki antrenman etkileri hakkında daha fazla bilgi sağlama potansiyeli göz önüne alındığında farklı sporlardaki nöromüsküler yükü ölçebilmek için daha iyi giyilebilir cihazların ve daha doğru sinyal filtreleme yaklaşımlarının geliştirileceği umulmaktadır.

\section{Antrenman Yük Hesabı ile Antrenmanların Yönlendirilmesi}

Antrenman yük araştırmalarının büyük bir kısmı, farklı durumlarda (örneğin, antrenman ve müsabaka sırasında) antrenman yükünü detaylandırarak ve karşılaştırarak tanımlamıştır. Bu çalışmaların faydası, antrenman yükünü ölçmek ve analiz etmek için yöntemler sağlamaktır. Ancak antrenman programına ve araştırmaya katılan sporculara bağlı oldukları için sonuçları genelleme veya karşılaştırma yapma konusunda sınırlı kalmaktadırlar (Cardinale ve Varley, 2017).

Uygulayıcılar sporcuları izlerken, çeşitli dış ve iç yük ölçümlerine sahiptir. Bu metriklerin, uygulayıcılara antrenman planlarını optimize etmelerine nasıl yardımcı olabileceği, her metriğe göre farklılık gösterebilir. Bir sporcunun vücut yüküne ilişkin bilgiler sporcuya uygulanan stresin bütünsel bir bilgisini sağlayabilir, ancak bu metriğe dayanan özel antrenman drilleri tasarlamak zordur. Belirli hızlarda kat edilen mesafelere ilişkin dış yükler, sporcuların antrenman programı içinde gerçekte neler yapabileceklerini planlamak için kullanılabilecek somut ölçümler arasında 
yer aldığı için uygulayıcılar tarafından kullanımı daha uygun olabilir. Benzer şekilde, yorgunluk, hız ve mesafeye dayalı antrenman yükü planlaması yapılırken dış yük kullanıldığında, vücut üzerindeki stresi tam olarak göstermesi olası değildir, bu nedenle vücut yükü, iç yük ve ivme ölçümleri de dahil edilmelidir (Boyd ve ark., 2011). Uygulayıcıların, antrenman planının her bir bileşeni için tüm ölçütleri kullanıp, kararlarının metriklere dayanması gerektiğini ve antrenman hedeflerini desteklemek için pratik bir şekilde elde edilen metriklerin kullanılabileceği düşünülmektedir.

Birçok çalışma, antrenman ve sakatlık arasındaki ilişkiyi araştırmıştır (Drew ve Finch, 2016). Antrenman yük ölçümleri genellikle hem akut (7 gün) hem de kronik (son 4 hafta) ve ikisi arasında bir oran olarak ölçülmüştür (Hulin ve ark., 2016). Kullanılan yük metriği, çalışmalar arasında değişmektedir, ancak toplam mesafe ve AAZD en yaygın olanı olarak görünmektedir. Hem yüksek hem de düşük yükler, sporcular için bireysel optimum yük eşiği olabileceği önerileriyle birlikte, sakatlık riskiyle ilişkilidir (Colby ve ark., 2014). Düşük antrenman yükü, antrenman veya müsabakalar için yeterince hazırlıksız olmasına neden olurken, kronik olarak yüksek yükler vücut üzerinde çok fazla strese neden olabilir. Bazı sporlarda akut ve kronik yük arasındaki etkileşimin, yüksek bir sakatlık riski ile ilişkili olduğu, sporcunun izlenmesindeki en önemli nedenin akut yükteki ani artışların belirlenmesi yönünde güçlü bir teori vardır (Gabbett, 2016). Kullanılan yönteme bakılmaksızın, sakatlık riskine katkıda bulunabilecek başka birçok faktör olduğu için, antrenman yükü bireysel bir perspektiften izlenmelidir (Drew ve Finch, 2016).

\section{Yük Takibiyle Antrenman Dozunun Belirlenip Sakatlıkların Önlenmesi}

Antrenman sürecine dahil olan tüm uygulayıcılar (antrenörler, fizyoterapistler, atletik performans antrenörleri) belirli performans seviyelerini ortaya çıkarmak için optimal antrenman miktarını belirleme ile ilgilenmektedirler. Antrenman programlarında kullanılan "doz-yanıt" ilişkisi, kimyagerlerin belirli bir ilacın olumlu ve olumsuz etkilerini anlamak istedikleri farmakolojik çalışmalarla benzerlik göstermektedir. Spor bilimcileri, sporcuları müsabakaya yönelik hazırlamak için fiziksel olarak zor bir antrenmanın gerekli olduğunu bilirler, ancak aşırı yüklenmenin sakatlanma riskinin artmasına neden olabileceğinin farkındadırlar (Bourdon ve ark., 2017).

Yapılan araştırmalar, antrenman yükü ile sakatlık arasında pozitif bir ilişki olduğunu ve daha yüksek yüklerde çalışmalar yapan sporcuların daha fazla sakatlıkla karşılaşabileceğini ortaya koymuştur (Gabbett, 2016). Yüksek miktarlarda hızlı koşular, yumuşak doku sakatlık riski ile 
ilişkilendirilmektedir (Hulin vd 2014). Antrenman yükündeki azalma ise daha az yaralanma ve aerobik kondisyonda daha fazla iyileşme ile sonuçlanmıştır. Bununla birlikte, yüksek kronik antrenman yüklerinin sporcuları sakatlıklara karşı koruyabildiğini gösteren önemli çalışmalarda bulunmaktadır (Soligard ve ark., 2016). Genel olarak bu sonuçlar, antrenman yükünün, sporcuları sakatlıklara karşı veya hasardan uzaklaştıran araç olarak tanımlanabileceğini göstermektedir (Bourdon ve ark., 2017). Yüksek antrenman yüklerinin etkisini bowling oyuncuları üzerinde ortaya koyan çalışmada, fazla atış yapan sporcuların dört haftalık kronik yükü daha fazla olduğu bulunmuştur (Hulin ve ark., 2014). Yüksek kronik yükü bulunan sporcuların, düşük kronik yükü olan sporculardan daha az sakatlık risklerinin olduğu ortaya koyulmuştur. Bu bulgular daha sonra geniş bir yelpazede farklı spor branşlarında Akut: Kronik İş Yükü Oranı (AKIYYO) metodunun kullanılmasına neden olmuştur. AKİYO (Akut Kronik İş Yükü Oranı) Banister tarafından kronik antrenman yüklerini karşılaştırmak için kullanan fitnes-yorgunluk modelinin basitleştirilmesidir (Banister, 1975). Bu analitik yaklaşımın son zamanlarda çeşitli sporculardaki sakatlık riskini tanımladığı bildirilmiştir (Murray ve ark., 2017). Bu modelle ortaya koyulan akut antrenman yükü, kronik antrenman yüküne yaklaşık olarak 0.8 ile 1.3 aralığında olduğunda sakatlık riskinin kontrol altında olduğu saptanmıştır (Hulin ve ark., 2014). Bununla birlikte, Şekil 2'de gösterildiği gibi AKİYO $\geq 1,5$ olduğunda (yani, akut antrenman yükü kronik antrenman yükünden çok daha fazla), yaralanma riski katlanarak artmaktadır (Blanch ve Gabbett, 2016).

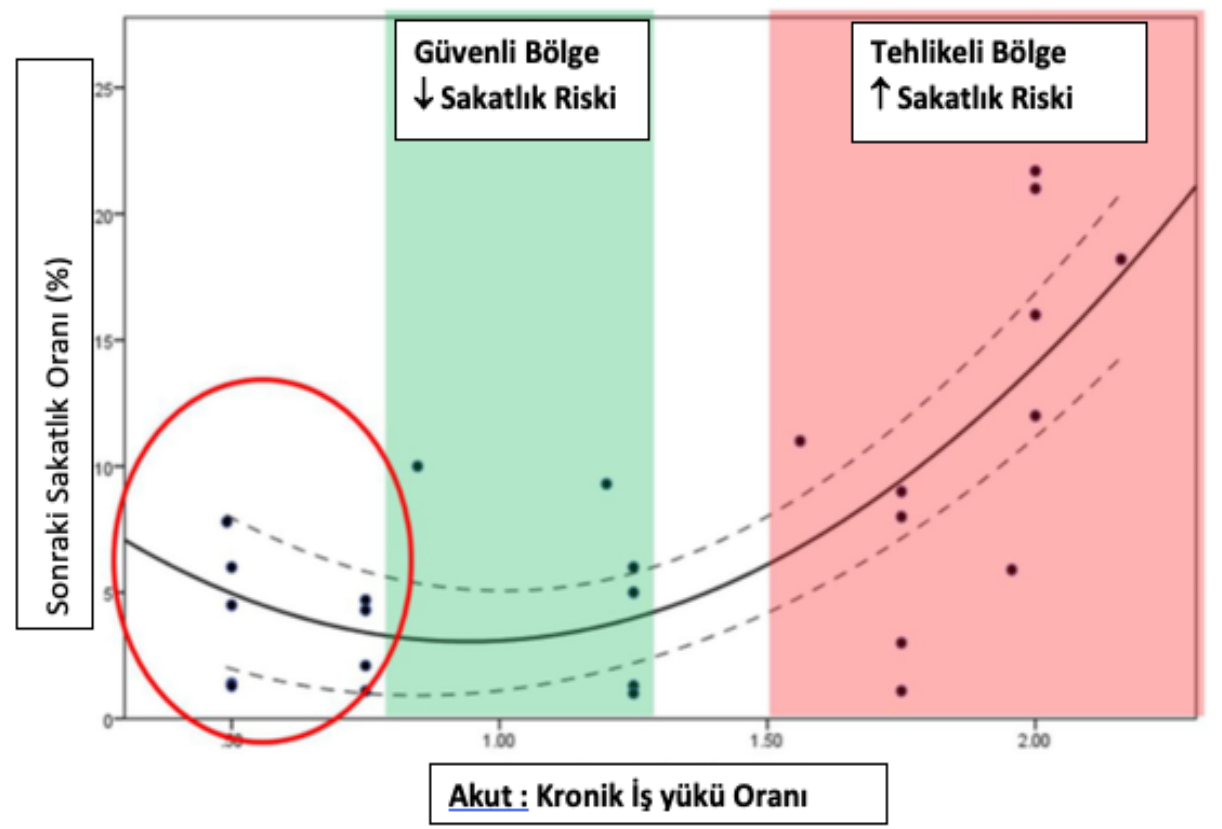

Şekil 2. Akut kronik iş yükü oranı ve sakatlık ilişkisi (Blanch ve Gabett ,2016) 
Antrenman yüklerinin günlük, haftalık, aylık, yıllık ve sezonlar arasındaki ilişkileriyle ilgili yapılan çalışmada yükler arasındaki oranın haftalık olarak da takip edilmesi gerektiğini bildirmektedir (Gabbett, 2016). Hesaplamalarda Şekil 3'de gösterildiği gibi haftalık yük değişiminin \%5 den fazla olmaması, diğer haftaya göre maksimum \%10'a kadar bir değişimin yapılması gerektiği aksi halde \%15'lik değişimler de sakatlık riskinin \%21 den \%49'a çıtığı bildirilmektedir (Gabbett ,2016).

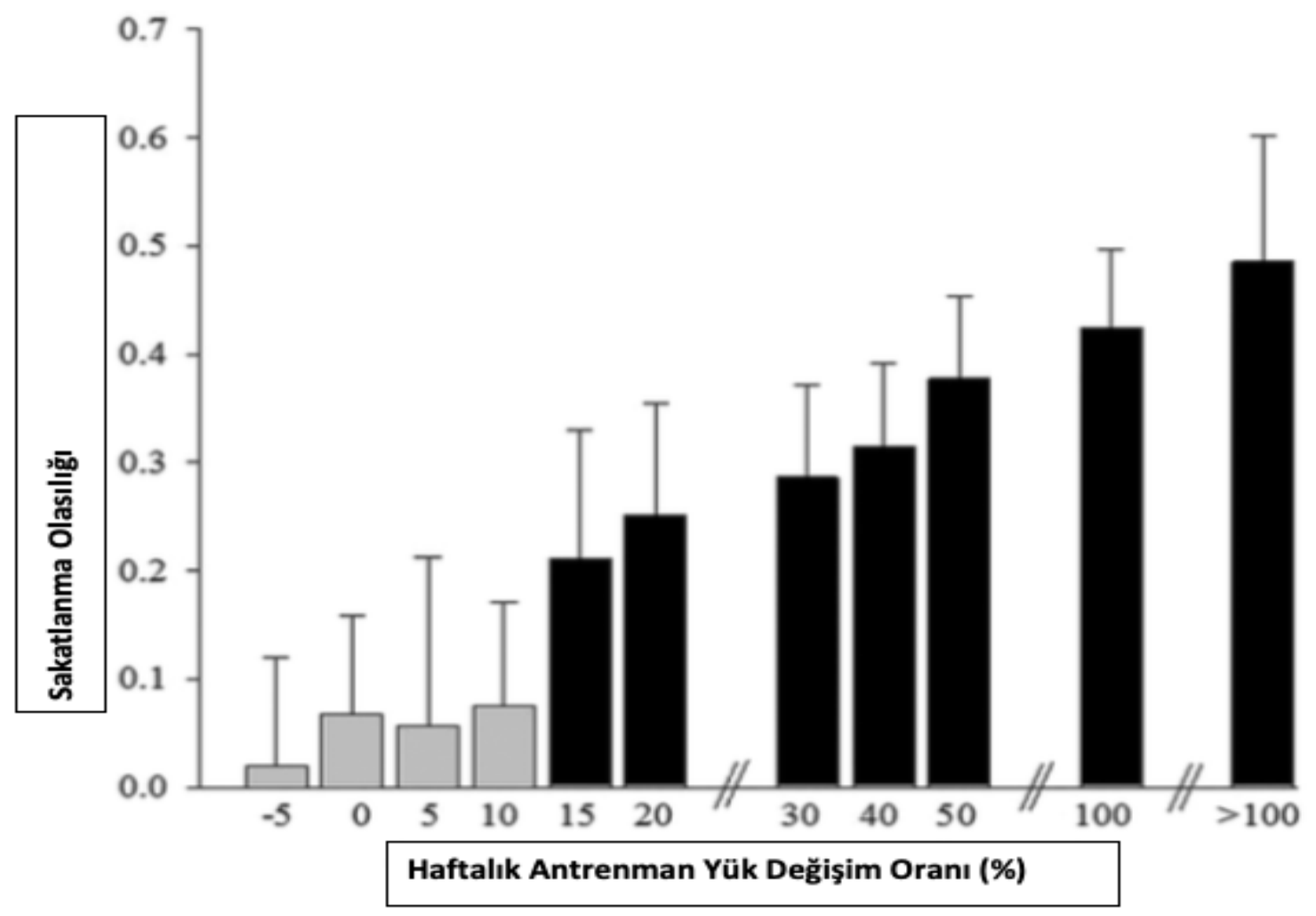

Şekil 3. Haftalık Yük Değişimi ve Sakatlık Riski İlişkisi (Gabbett, 2016)

Sadece sporculara uygulatılan antrenmanların fazlalığı sakatlığa neden olmamaktadır, düşük antrenman yükü oranı da fazla antrenman yükünün fazlalığı gibi sakatlık da etkilidir (Gabbett, 2016; Hulin ve ark., 2014). Bu nedenle Şekil 4' de gösterildiği gibi sporcuların sakatlıkları ve fiziksel performansları arasında pozitif yönde ilişki tespit edilmiştir (Gabbett, 2016). Antrenman yükü takibinde 0.8 oranının altına düşmemesi 1.3 oranının üstüne çıkmaması yük yönetiminde istenen sonuçtur ancak oyuncuların bireysel performans farklılıkları bu kontrolü zorlaştırmaktadır (Malone ve ark., 2018). Oyuncuların lig düzeyi ve kapasiteleri artıkça ortaya koydukları fiziksel performans ligin ve oyunun kalitesiyle paralellik göstererek artmaktadır. Ortaya çıkan 
performansın artmasıyla iş yükünün artması bunanla beraber sakatlıkların ortaya çıkması kaçınılmaz bir durumdur. Son yıllarda müsabaka şiddetlerinin artmasıyla sporcuların yüksek iç ve dış yüklere lig ve maç gereksinimi nedeniyle maruz kalması söz konusu olduğu için sakatlık riskini kontrol altında tutmanın en iyi yönlerinden bir tanesi de oyuncuların fiziksel performans düzeylerini arttırarak yüke toleranslarını daha dayanıklı hale getirmektir. Bu mantıkta oyuncunun hafta sonu yaptığı müsabaka şiddetinin düşürülememesi, aynı zamanda bu müsabaka şiddetine karşı takımın hazır olma isteği, oyuncuların şiddeti ve hacmi azaltarak değil o şiddetteki ve hacimdeki yükleri daha iyi tolere edip, sakatlık risk eşiklerini üst seviyeye çıkartmayı istemeleri fiziksel performansı arttırarak gerçekleşmektedir. Oyuncuların aerobik ve anaerobik performanslarının artması ya da azalmasıyla oyuncuların yükü toleranslarında değişkenliklerin olduğu yapılan çalışmada bildirilmiştir (Malone ve ark., 2018). Oyuncuların fiziksel performanslarının artmasıyla kat ettikleri mesafeler, anaerobik kapasitelerinin artmasıyla sprint mesafelerinin arttığı çalışmalar tarafından ortaya koyulmuştur (Mohr ve ark., 2003; Aquino ve ark., 2018). Sporcuların alt vücut kuvvetiyle yük toleranslarını karşılaştıran çalışmada ise alt vücut kuvveti yüksek olan sporcuların yükü toleranslarının daha fazla olduğu bildirilmiştir (Malone ve ark., 2018).

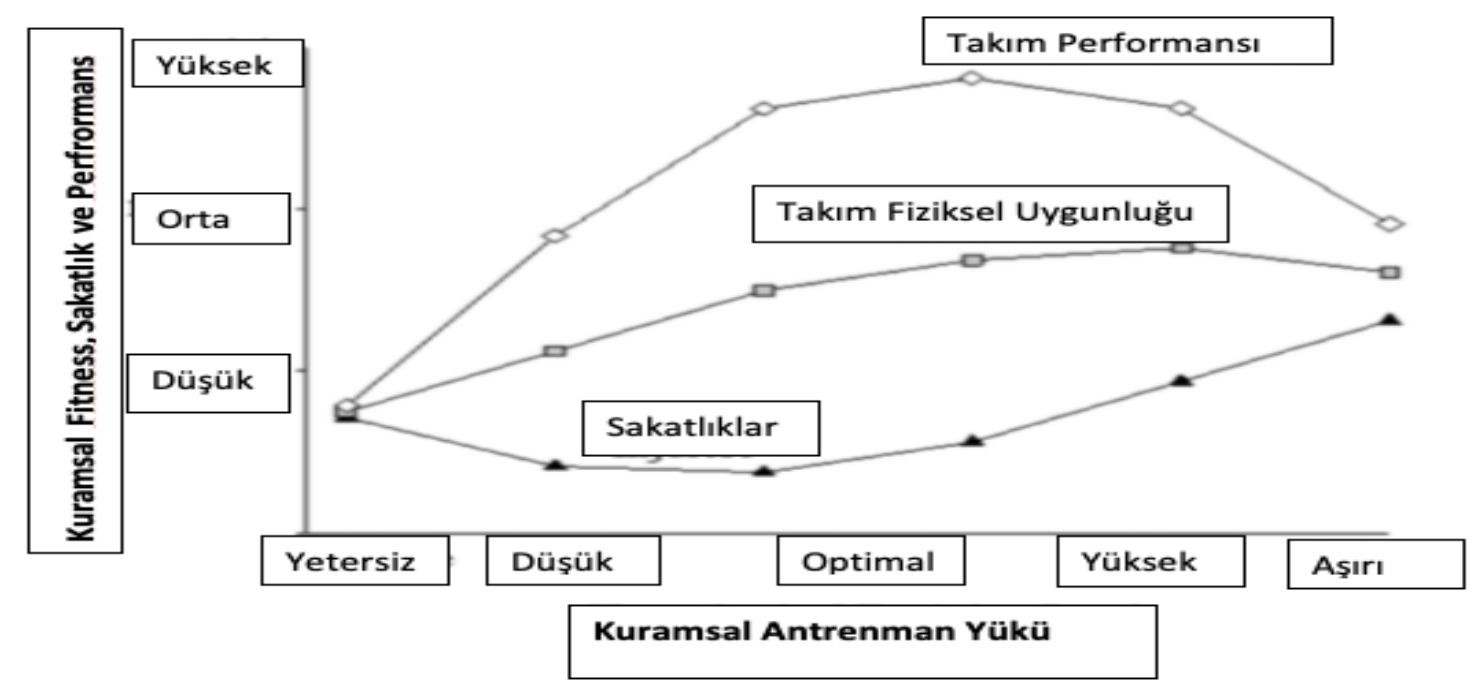

Şekil 4. Sporcuların Fiziksel Kapasite ve Sakatlık İlişkisi (Orchard, 2012) 


\section{SONUÇ VE ÖNERILER}

Antrenman ve müsabaka yükü verilerinin elde edilip ve değerlendirilmesi, elit sporcularda uzun bir geçmişe sahiptir. Spora özgü çeşitli yöntemlerde, her değişken kendi güçlü yanlarının beraberinde kısıtlılıklarını getirmektedir, güçlü yanları ve kısıtlılıkları sporcuya destek veren uygulayıcılar tarafından anlaşılmalıdır. Yeni analitik yaklaşımların ortaya çıkmasıyla birlikte yeni teknolojilerin ortaya çıkması, performansı ve sakatlık riskini öngören daha güçlü araçların yakında piyasaya sürüleceğini ortaya koymaktadır (Bourdon ve ark., 2017). Bununla birlikte hem artan araştırma miktarlarına hem de yüksek performanslı programlarda yük takibinin popülerliğine rağmen, bugüne kadar antrenman ve fitness performansındaki yorgunluk tepkilerini doğru bir şekilde ölçebilecek tek bir ölçüm belirlenmemiştir. (Mujika, 2017). Antrenman yüklerinin spora özgü kombinasyonları seçilmeli, antrenman yükünün bireysel olarak sporcuların farklılıklarına göre şekillendirilmesi ve sporcuların sakatlık risklerinin azaltırken performanslarının artırılmasını sağlayan pratik antrenman yükü takip yöntemleri kullanılmalıdır. Sporcuların yük takiplerinin niteliği, spora bağlı olarak çok farklı olabilir ve genellikle birden fazla takip aracı kullanılabilir. Bireysel fizyolojik adaptasyonun ve egzersize verilen tepkilerin yanı sıra, farklı sporlarla ilgili olması gereken özgüllüğün bir sonucudur. Bununla birlikte, yapılan yeni çalışmalar birçok sporcunun, antrenörün ve destek ekibinin, yükü takibi için giderek daha bilimsel bir yaklaşım izlediğini göstermektedir.

Yük takibi için bilimsel prensiplerin kullanılması, işlevsel olmayan aşırı antrenman, hastalık ve sakatllk riskini azaltmanın önemli bir yolu olabilir. Yüksek antrenman yüklerine ve yüksek müsabaka streslerine maruz kalan birçok sporcunun, antrenman yükünün olumsuz sonuçlarıyla ilişkili olabilecek risklerin yönetilmesi, sporcunun fizyolojik ve psikolojik sağlığının en iyi şekilde sürdürülmesi gerekmektedir. Dış ve iç yük ölçümü için birçok yöntem tanımlanmış olsa da yükün izlenmesinde ve bunlara karşı nedenlerin belirlenmesinde, spor ve birey için gerekli olan spesifik yük takip türünün ve yük değişiminin uygun bir şekilde değerlendirilmesinde çok sayıda değişken faktör yer almaktadır. Sporcuya ve antrenöre doğru ve yorumlanması kolay bir geri bildirim sağlanırsa, yük takibi antrenman yanıtlarının daha iyi bilinmesine, antrenman programlarının daha kaliteli tasarlanmasına yardımcı olabilir. Bu nedenle elde edilecek verilerin kaliteli hale getirilmesi için sporcular ve teknik ekiplerin aralarındaki iletişimi güçlendirmeleri tavsiye edilmektedir. Antrenman yükleri ile sakatlık arasında pozitif yönde ilişki olmasına karşın sakatıkların tek 
nedenin yükteki fazlalıktan kaynaklı değil, sporculara uygun olmayan doğru planlanmamış antrenmanlardan da kaynaklandığı kanıtlanmıştır (Gabbett, 2016).

Antrenman yüklerindeki aşırı ve ani artışlar, büyük oranda temassız yumuşak doku sakatliklarından sorumludur. Bununla birlikte, fiziksel olarak zor fakat sporcu için uygun antrenmanlar sporcuları sakatlanmaya karşı koruyan fiziksel özelliklerini optimum düzeyde geliştirmektedir. Sporcuları sakatlık risklerinden korumak, uzun vadede spor hayatlarını devam etmelerine olanak sağlayabilmek ve milyon dolarlık oyuncularını sakatlıklarından koruyarak maliyet problemleri gibi negatif durumlardan kulüplerin kaçınabilmesini sağlamak için antrenman yükünün takibi oldukça önemlidir. Spor bilimciler ve uygulayıcıların antrenmanlarını sağlam temellere oturtup, antrenmanlarında hedefledikleri optimum performansı güvenli bir şekilde elde edebilmeleri için, antrenman yüklerini takip edip çeşitli yöntemleriyle sonuçlarını analiz ederek antrenmanlarına yön vermeleri önerilmektedir.

\section{KAYNAKLAR}

Abt, G., \& Lovell, R. (2009). The use of individualized speed and intensity thresholds for determining the distance run at high-intensity in professional soccer. Journal of Sports Sciences, 27(9), 893-898.

Akenhead, R., French, D., Thompson, K. G., \& Hayes, P. R. (2014). The acceleration dependent validity and reliability of $10 \mathrm{~Hz}$ GPS. Journal of Science and Medicine in Sport, 17(5), 562-566.

Akubat, I., Barrett, S., Sagarra, M. L., \& Abt, G. (2018). The Validity of External: Internal Training Load Ratios in Rested and Fatigued Soccer Players. Sports, 6(2), E44. doi: 10.3390/sports6020044

Akyıldız, Z. (2018). Futbolcularda Yapılan Anaerobik ve Aerobik Performans Testleriyle Saha Takip Cihazlarlyla Elde Edilen Fizyolojik ve Kinematik Parametrelerin Karşılaştırılması, Yüksek Lisans Tezi, Afyon Kocatepe Üniversitesi, Sağlık Bilimleri Enstitüsü.

Alemdaroğlu, B. U., \& Köklü, Y. (2017). Antrenman yükü takibi ve sakatlık önlemedeki rolü. Türkiye Klinikleri Sports Medicine-Special Topics, 3(3), 184-190.

Aquino, R., Palucci, L. V., Cruz, L. G., \& Pereira, P. S. (2018). Relationship between field tests and match running performance in high-level young Brazilian soccer players. The Journal of Sports Medicine and Physical Fitness, 58(3), $256-262$.

Aslan, A., Acikada, C., Güvenç, A., Gören, H., Hazir, T., \& Özkara, A. (2012). Metabolic demands of match performance in young soccer players. Journal of Sports Science \& Medicine, 11(1), 170.

Banister, E. W. (1991). Modeling elite athletic performance. In: Physiological testing of elite athletes (Green HJ, McDougal JD, Wenger H, eds) Human Kinetics, Campaign Ill., pp 403-424

Banister, E. W., Calvert, T. W., Savage, M. V., \& Bach, T. (1975). A systems model of training for athletic performance. Australian Journal of Sports Medicine. 7(3), 57-61.

Bartlett, J. D., O’Connor, F., Pitchford, N., Torres-Ronda, L., \& Robertson, S. J. (2017). Relationships between internal and external training load in team-sport athletes: evidence for an individualized approach. International Journal of Sports Physology and Performance, 12(2), 230-234.

Blanch, P., \& Gabbett, T. J. (2016). Has the athlete trained enough to return to play safely? The acute: chronic workload ratio permits clinicians to quantify a player's risk of subsequent injury. British Journal of Sports Medicine, 50(8), 471-475. 
Borg, G. A. (1982). Psychophysical bases of perceived exertion Medicine and Science in Sports and Exercise 14(5), $377-381$.

Bourdon, P. C., Cardinale, M., Murray, A., Gastin, P., Kellmann, M., Varley, M. C., ... \& Cable, N. T. (2017). Monitoring athlete raining loads: consensus statement. International Journal of Sports Physiology and Performance, 12(Suppl 2), S2-161.

Boyd, L. J., Ball, K., \& Aughey, R. J. (2011). The reliability of MinimaxX accelerometers for measuring physical activity in Australian football. International Journal of Sports Physiology and Performance, 6(3), 311-321.

Brito, J., Hertzog, M., \& Nassis, G. P. (2016). Do match-related contextual variables influence training load in highly trained soccer players?. The Journal of Strength \& Conditioning Research, 30(2), 393-399.

Buchheit, M. (2016). The numbers will love you back in return-I promise. International Journal of Sports Physiology and Performance, 11(4), 551-554.

Cardinale, M., \& Varley, M. C. (2017). Wearable training-monitoring technology: Applications, challenges, and opportunities. International Journal of Sports Physiology and Performance, 12(Suppl 2), S2-55.

Cheron, G., Petit, G., Cheron, J., Leroy, A., Cebolla, A., Cevallos, C., ... \& Dan, B. (2016). Brain oscillations in sport: toward EEG biomarkers of performance. Frontiers in Psychology, 7, 246.

Colby, M. J., Dawson, B., Heasman, J., Rogalski, B., \& Gabbett, T. J. (2014). Accelerometer and GPS-derived running loads and injury risk in elite Australian footballers. The Journal of Strength \& Conditioning Research, 28(8), 2244-2252.

Collette, R., Kellmann, M., Ferrauti, A., Meyer, T., \& Pfeiffer, M. (2018). Relation Between Training Load and Recovery-Stress State in High-Performance Swimming. Frontiers in Psychology,, 9.

Cummins, C., Orr, R., O’Connor, H., \& West, C. (2013). Global positioning systems (GPS) and microtechnology sensors in team sports: a systematic review. Sports Medicine, 43(10), 1025-1042.

Di Prampero, P. E., Fusi, S., Sepulcri, L., Morin, J. B., Belli, A., \& Antonutto, G. (2005). Sprint running: a new energetic approach. Journal of Experimental Biology, 208(14), 2809-2816.

Drew, M. K., \& Finch, C. F. (2016). The relationship between training load and injury, illness and soreness: a systematic and literature review. Sports Medicine, 46(6), 861-883.

Edgecomb, S. J., \& Norton, K. I. (2006). Comparison of global positioning and computer-based tracking systems for measuring player movement distance during Australian football. Journal of Science and Medicine in Sport, 9(1-2), 25-32.

Finni, T., Hu, M., Kettunen, P., Vilavuo, T., \& Cheng, S. (2007). Measurement of EMG activity with textile electrodes embedded into clothing. Physiological Measurement, 28(11), 1405.

Foster, C. A. R. L. (1998). Monitoring training in athletes with reference to overtraining syndrome. Medicine and Science in Sports and Exercise, 30, 1164-1168.

Foster, C., Rodriguez-Marroyo, J. A., \& De Koning, J. J. (2017). Monitoring training loads: the past, the present, and the future. Journal of Science and Medicine in Sport, 12(Suppl 2), 22-28.

Gabbett, T. J. (2013). Quantifying the physical demands of collision sports: does microsensor technology measure what it claims to measure?. The Journal of Strength \& Conditioning Research, 27(8), 2319-2322.

Gabbett, T. J. (2016). The training - injury prevention paradox: should athletes be training smarter and harder?. British Journal of Sports Medicine, 50(5), 273-280.

Gabbett, T. J. (2010). GPS analysis of elite women's field hockey training and competition. The Journal of Strength \& Conditioning Research, 24(5), 1321-1324

Gao, W., Emaminejad, S., Nyein, H. Y. Y., Challa, S., Chen, K., Peck, A., ... \& Lien, D. H. (2016). Fully integrated wearable sensor arrays for multiplexed in situ perspiration analysis. Nature, 529 (7587):509-514.

Hackney, A. C. (2013). Clinical management of immuno-suppression in athletes associated with exercise training: sports medicine considerations. Acta Medica Iranica, 51(11), 751-756.

Halson, S. L. (2014). Monitoring training load to understand fatigue in athletes. Sports Medicine, 44(2), 139-147. 
Hewitt, A. (2016). Performance Analysis in Soccer: Applications of Player Tracking Technology (Doctoral dissertation, University of Canberra).

Hooton, K., Han, W., \& Li, L. (2016). Comprehensive and Quantitative Profiling of the Human Sweat Submetabolome Using High-Performance Chemical Isotope Labeling LC-MS. Analytical Chemistry, 88(14), 7378-7386.

Hulin, B. T., Gabbett, T. J., Blanch, P., Chapman, P., Bailey, D., \& Orchard, J. W. (2014). Spikes in acute workload are associated with increased injury risk in elite cricket fast bowlers British Journal of Sports Medicine, 48(8), 708-712.

Hulin, B. T., Gabbett, T. J., Johnston, R. D., \& Jenkins, D. G. (2018). Playerload variables are sensitive to changes in direction and not related to collision workloads in rugby league match-play. International Journal of Sports Physiology and Performance,13(9),1136-1142

Hulin, B. T., Gabbett, T. J., Lawson, D. W., Caputi, P., \& Sampson, J. A. (2016). The acute: chronic workload ratio predicts injury: high chronic workload may decrease injury risk in elite rugby league players. British Journal of Sports Medicine, 50(4), 231-236.

Jennings, D., Cormack, S., Coutts, A. J., Boyd, L., \& Aughey, R. J. (2010).The validity and reliability of GPS units for measuring distance in team sport specific running patterns. Journal of Science and Medicine in Sport, 5(3), 328341.

Kim, D. H., Lu, N., Ma, R., Kim, Y. S., Kim, R. H., Wang, S., ... \& Yu, K. J. (2011). Epidermal Electronics. Science, 333(6044), 838-843.

Malone, S., Owen, A., Mendes, B., Hughes, B., Collins, K., \& Gabbett, T. J. (2018). High-speed running and sprinting as an injury risk factor in soccer: Can well-developed physical qualities reduce the risk?. Journal of Science and Medicine in Sport, $21(3), 257-262$.

McCaskie, C. J., Young, W. B., Fahrner, B. B., \& Sim, M. (2018). Association Between Pre-season Training and Performance in Elite Australian Football. International Journal of Sports Physiology and Performance, 12:1-25.

McGuigan, M. (2017). Monitoring training and performance in athletes. Human Kinetics.

Mohr, M., Krustrup, P., \& Bangsbo, J. (2003). Match performance of high-standard soccer players with special reference to development of fatigue. Journal of Sports Sciences, 21(7), 519-528.

Montini, M., Felici, F., Nicolo, A., Sacchetti, M., \& Bazzucchi, I. (2017). Neuromuscular demand in a soccer match assessed by a continuous electromyographic recording. The Journal of Sports Medicine and Physical Fitness, 57(4), 345-352.

Mujika, I. (2017). Quantification of training and competition loads in endurance sports: methods and applications. International Journal of Sports Physiology and Performance, 12(Suppl 2), 29-217.

Murray, N. B., Gabbett, T. J., Townshend, A. D., Hulin, B. T., \& McLellan, C. P. (2017). Individual and combined effects of acute and chronic running loads on injury risk in elite Australian footballers. Scandinavian Journal of Medicine \& Science in Sports, 27(9), 990-998.

Orchard, J. (2012). Who is to blame for all the football injuries? [Available online at: https://blogs.bmj.com/bjsm/2012/06/20/who-is-to-blame-for-all-the-football-injuries/], Erişim tarihi: 25 Mart 2019

Osgnach, C., Poser, S., Bernardini, R., Rinaldo, R., \& Di Prampero, P. E. (2010). Energy cost and metabolic power in elite soccer: a new match analysis approach. Medicine \& Science in Sports \& Exercise, 42(1), 170-178.

Polglaze, T., Dawson, B., Hiscock, D. J., \& Peeling, P. (2015). A Comparative Analysis of Accelerometer and Time-Motion Data in Elite Men's Hockey Training and Competition. International Journal of Sports Physiology and Performance, 10(4), 446-451.

Rampinini, E., Alberti, G., Fiorenza, M., Riggio, M., Sassi, R., Borges, T. O., \& Coutts, A. J. (2015). Accuracy of GPS devices for measuring high-intensity running in field-based team sports. International Journal of Sports Medicine, 36(01), 49-53.

Schwartz, G., Tee, B. C. K., Mei, J., Appleton, A. L., Kim, D. H., Wang, H., \& Bao, Z. (2013). Flexible polymer transistors with high pressure sensitivity for application in electronic skin and health monitoring. Nature Communications, 4, 1859. doi: $10.1038 /$ ncomms 2832 .

Scott, M. T., Scott, T. J., \& Kelly, V. G. (2016). The validity and reliability of global positioning systems in team sport: a brief 
review. The Journal of Strength \& Conditioning Research, 30(5), 1470-1490.

Soligard, T., Schwellnus, M., Alonso, J. M., Bahr, R., Clarsen, B., Dijkstra, H. P., ... \& Van Rensburg, C. J. (2016). How much is too much?(Part 1) International Olympic Committee consensus statement on load in sport and risk of injury. British Journal of Sports Medicine, 50(17), 1030-1041.

Sparks, M., Coetzee, B., \& Gabbett, T. J. (2017). Internal and external match loads of university-level soccer players: A comparison between methods. The Journal of Strength \& Conditioning Research, 31(4), 1072-1077.

Townshend, A. D., Worringham, C. J., \& Stewart, I. B. (2008). Assessment of speed and position during human locomotion using nondifferential GPS. Medicine \& Science in Sports \& Exercise, 40(1), 124-132.

Varley, M. C., Fairweather, I. H., \& Aughey1, 2, R. J. (2012). Validity and reliability of GPS for measuring instantaneous velocity during acceleration, deceleration, and constant motion. Journal of Sports Sciences, 30(2), 121-127. 